\title{
AN EVALUATION OF ANTIOXIDANT, ANTIMICROBIAL, ANTIBIOFILM AND CYTOTOXIC ACTIVITIES OF FIVE VERBASCUM SPECIES IN TURKEY
}

\author{
BURCU SEN-UTSUKARCI ${ }^{1 *}$, SIBEL DOSLER ${ }^{2}$, TURGUT TASKIN $^{3}$, MAHMOUD ABUDAYYAK $^{4}$, \\ GUL OZHAN $^{5}$, AFIFE MAT ${ }^{1}$ \\ ${ }^{1}$ Istanbul University, Faculty of Pharmacy, Department of Pharmacognosy, 34116, Beyazit, Istanbul, Turkey \\ ${ }^{2}$ Istanbul University, Faculty of Pharmacy, Department of Pharmaceutical Microbiology, 34116, Beyazit, Istanbul, Turkey \\ ${ }^{3}$ Marmara University, Faculty of Pharmacy, Department of Pharmacognosy, 34668, Haydarpasa, Istanbul, Turkey \\ ${ }^{4}$ Karadeniz Technical University, Faculty of Pharmacy, Department of Pharmaceutical Toxicology, 61000, Trabzon, Turkey \\ ${ }^{5}$ Istanbul University, Faculty of Pharmacy, Department of Pharmaceutical Toxicology, 34116, Beyazit, Istanbul, Turkey
}

*corresponding author: burcusn@gmail.com

Manuscript received: December 2017

\begin{abstract}
Verbascum L. species are used for different medicinal purposes in Turkish folk medicine such as diuretic, expectorant, laxative, mucolytic, sedative, sudorific, and wound healer. Five Verbascum species, two of which are used in medicine, were investigated for their antimicrobial, antioxidant and cytotoxic activities. Determination of the total phenolic compounds, DPPH and ABTS methods were preferred for the antioxidant tests. The antimicrobial and antibiofilm activities of the extracts, which were not studied previously, were investigated against pathogenic and potential pathogenic agents. The cytotoxicity was assessed by MTT and LDH tests. This study is very important for finding new therapeutic sources and also new, natural sources for food preservation.
\end{abstract}

\section{Rezumat}

Speciile Verbascum L. sunt utilizate în scopuri medicinale diferite în medicina populară turcă, cum ar fi diuretic, expectorant, laxativ, mucolitic, sedativ, sudorific și cicatrizant. Cinci specii Verbascum, dintre care două sunt utilizate în scop medicinal, au fost investigate pentru activitățile lor antimicrobiene, antioxidante şi citotoxice. Pentru evaluarea capacității antioxidante s-au determinat compuşii fenolici totali şi testele specifice prin metoda DPPH şi ABTS. Activităţile antimicrobiană şi antibiofilm ale extractelor, care nu au fost studiate anterior, au fost investigate împotriva agenţilor patogeni şi potențiali patogeni. Citotoxicitatea a fost evaluată prin teste MTT şi LDH. Acest studiu are o importanță deosebită pentru găsirea de noi surse terapeutice şi, de asemenea, pentru noi surse naturale de conservanți alimentari.

Keywords: Verbascum species, antioxidant, antimicrobial, antibiofilm, cytotoxicity, food preservation

\section{Introduction}

Due to the appearance of undesirable side effects of certain commercial antioxidants, an increased interest in antioxidant activity of plants has been registered in recent years. A great number of bioactive compounds with antioxidant activity have important roles in free radical chain reactions [1]. Similarly, studies on the antimicrobial activity have increased over the years. Researchers also focus on finding out new antimicrobial agents from plant sources. Based on drugresistant infections 25,000 people die every year in Europe. The antibiotic resistance has reached a critical point, as human and economic costs escalate. For some pathogens, the choice of available drugs is now greatly reduced [36]. Beside of this, the antimicrobial agents have an important role in food conservation. The food industry tries to find alternative natural sources, especially green chemicals, instead of the chemical preservatives [4]. The tendency to green chemicals increase day after day. Therefore, the investigations on antioxidant and antimicrobial activities of plants became crucial. Also, the cytotoxicity of new drugs/ sources is very important from the standpoint of cell damage.

The genus Verbascum L. is represented by 360 species, approximately, worldwide. In Turkey, it comprises about 249 species, of which 191 are endemic [9, 13, 15, 18, 23-27]. In traditional Turkish folk medicine, Verbascum species, commonly known as "sigirkuyrugu", have been used as anti-diarrheic, diuretic, mucolytic, expectorant, sedative, sudorific and wound healer [2, $33,38]$. The species of this genus contain flavonoids, iridoid glucosides, neolignan glucosides, phenylethanoid glycosides, saponins, spermine alkaloids, steroids, etc. In modern phytotherapy, $V$. densiflorum, $V$. phlomoides and $V$. thapsus L. are recognized as medicinal plants. V. lagurus Fisch. \& C. A. Mey (VL) is wide spread in the Marmara Region, Turkey. Previously, we investigated 
the antimicrobial activity of some extracts of this species and the chemical content of the active extract. Three flavonoids, three phenylethanoid compounds and two phenolic acids were isolated from the EtOAc (ethylacetate) extract [30]. Furthermore, we have compared the antimicrobial activities of different extracts from $V$. densiflorum Bertol. (VD), $V$. gnaphalodes Bieb. (VG), V. lagurus (VL), V. phlomoides L. (VP), V. xanthophoeniceum Griseb. (VX) [31].

Additionally, three studies on $V$. xanthophoeniceum exist in literature. The antioxidant and cholinesterases inhibitory activities of Verbascum xanthophoeniceum and its phenylethanoid glycosides were investigated by various methods. The anti-inflamatory effect of crude methanol extract, its subfraction and isolated compounds (iridoid glycosides and phenylethanoid glycosides) were also determined on human keratinocytes. Beside of these, the cytotoxicity and inhibitory effect on DHT-induced PSA secretion of crude methanol extract and its isolated phenylethanoid glycoside (verbascoside) in an in vitro model of human prostate epithelium were designated $[15,16,20]$.

Because of the few studies on these Verbascum species and because a comparison between their activities and those of the medicinal species, it is aimed to improve and develop the previous studies and to determine the activity potentials of different extracts from these species.

\section{Materials and Methods}

Plant material: Verbascum xanthophoeniceum (VX) Verbascum densiflorum (VD) and Verbascum lagurus (VL) were collected from Kirklareli-Demirkoy, Turkey and Verbascum gnaphalodes Bieb. (VG) from YalovaArmutlu, Turkey, in May 2009 and identified by Prof. Emine Akalin (Istanbul, Turkey). The voucher specimen has been deposited in the Herbarium of the Faculty of Pharmacy, Istanbul University (ISTE 91932; 91869; 91931; 92498). Verbascum phlomoides (VP) were provided from "Kurtsan Holding".

Preparation of extracts: The dried and powdered aerial parts of 5 Verbascum species were extracted in a Soxhlet apparatus with methanol $(\mathrm{MeOH})$. The concentrated extract was diluted with water and extracted with petroleum ether (PE) in a separating funnel. The aqueous phase was successively extracted with toluene, chloroform and ethyl acetate (EtOAc). There were obtained several extracts: $\mathrm{Me}-\mathrm{OH}, \mathrm{PE}$, Tol, $\mathrm{CHCl}_{3}$ and EtOAc. All extracts were stored at $\pm 4^{\circ} \mathrm{C}$ after preparation.

Antioxidant assay:

Chemicals and reagent for antioxidant activity: 2,2-diphenyl-1-picrylhydrazyl (DPPH•), Folin-Ciocâlteu's phenol reagent $2 \mathrm{~N}$, gallic acid and ascorbic acid were obtained from Sigma Chemical Co., USA. All other reagents were of analytical grade.
DPPH• radical scavenging activity: The DPPH radical scavenging activities of different extracts were measured by the DPPH • method proposed by Wei et al. [39]. A DPPH solution $(0.1 \mathrm{mM}, 3.9 \mathrm{~mL})$ was added to extracts $(0.1 \mathrm{~mL})$ prepared at different concentrations. Then the mixture was allowed to stand at room temperature for $30 \mathrm{~min}$. The absorbance of the mixture was measured against the reference using a spectrophotometer at $517 \mathrm{~nm}$.

ABTS $^{\cdot^{+}}$radical-scavenging activity: The $\mathrm{ABTS}^{\cdot+}$ assay was performed according to the method developed by $\mathrm{Re}$ et al. [29]. $40 \mu \mathrm{L}$ of extracts prepared from plant material, $3960 \mu \mathrm{L}_{\text {of }} \mathrm{ABTS}^{\cdot+}$ working solution were combined. The absorbance of the mixture was measured against the reference at $734 \mathrm{~nm}$ for $6 \mathrm{~min}$. The data obtained in this study were expressed as $\mathrm{mM}$ trolox/mg extract.

Determination of total phenolic compounds: The different extracts were placed in $0.1 \mathrm{~mL}$ tubes and $4.5 \mathrm{~mL}$ of water was added to them. Then FolinCiocâlteu reagent (diluted $1 / 3$ with distilled water) and $0.3 \mathrm{~mL}$ of $2 \%$ sodium carbonate solution were added to the mixture. The mixture was allowed to stand at room conditions for 2 hours, and then the absorbance was measured at $760 \mathrm{~nm}$ against the reference. The total phenolic content in the extracts was expressed as mg gallic acid equivalents /mg extract [34].

Antimicrobial assay: In vitro antibacterial activities of the toluene extracts against Staphylococcus aureus ATCC 6538, Staphylococcus epidermidis ATCC 12228, Enterococcus faecalis ATCC 29212; Escherichia coli ATCC 25922, Klebsiella pneumoniae ATCC 4352, Pseudomonas aeruginosa ATCC 27853, Proteus mirabilis ATCC 14153 and antifungal activities against Candida albicans ATCC 10231 were investigated, as like as the other extracts, which were tested in our previous study. Minimum inhibitory concentrations (MICs) of compounds were determined by microbroth dilution technique as described by the Clinical and Laboratory Standards Institute (CLSI) $[5,6]$.

For this purpose, serial two-fold dilutions of extracts ranging from $5000 \mu \mathrm{g} / \mathrm{mL}$ to $9.76 \mu \mathrm{g} / \mathrm{mL}$ were prepared in Mueller-Hinton Broth (MHB) (Difco, Detroid, USA) for bacteria and RPMI-1640 (Sigma) medium for yeast. The inoculums were diluted in broth media to give a final concentration of $5 \times 10^{5} \mathrm{CFU} / \mathrm{mL}$ for bacteria and $0.5 \times 10^{3}$ to $2.5 \times 10^{3} \mathrm{CFU} / \mathrm{mL}$ for yeast in the test tray. The trays were incubated at $37^{\circ} \mathrm{C}$ for $18-24 \mathrm{~h}$. The MIC was defined as the lowest concentration of compound giving complete inhibition of visible growth. To verify the standardization of test procedure, ciprofloxacin and fluconazole were used as reference substances for bacteria and yeast, respectively.

Antibiofilm Assay: For determination of anti-biofilm activities of extracts, the measurements of the minimum biofilm eradication concentration (MBEC) values were assessed against bacterial and $C$. albicans biofilms as 
FARMACIA, 2018, Vol. 66, 6

previously described [21]. Serial 2-fold dilutions of extracts ranging from 10000 to $625 \mathrm{mg} / \mathrm{L}$ were prepared in MHB, and added to the $24 \mathrm{~h}$ biofilms in a 96 well tissue culture microtiter plates. After the $24 \mathrm{~h}$ incubation at $37^{\circ} \mathrm{C}$, the plates were washed, sonicated for disrupting the biofilms and samples were plated on TSA for colony counts. MBEC was defined as the lowest concentration of extracts which microorganism fails to regrow after exposure. All experiments were performed in two independent assays [12].

Cytotoxic Assay

The cytotoxic effects of all extracts on NRK-52E rat kidney cell line (NRK-52E) (ATCC, USA) were evaluated using MTT and LDH assays. The cells were seeded into 96-well plates at a density of $10^{4}$ cells/ well, and incubated at $37^{\circ} \mathrm{C}$ and $5 \% \mathrm{CO}_{2}$ for $24 \mathrm{~h}$. Then, the cells exposed to the extracts in the range of $0.005-0.5 \mathrm{mg} / \mathrm{mL}$ concentrations. Dimethylsulfoxide (DMSO) was used as solvent control, non-exposed cells as growth control and $10 \%$ triton-X100 as positive control. Assays were performed in triplicates, and each test was repeated three times $(n=9)$. For both tests, $\mathrm{IC}_{50}$ values were defined as the concentrations of compounds required to reduce the absorbance to $50 \%$ of the control values.

For MTT test, $20 \mu \mathrm{L}$ of MTT solution $(5 \mathrm{mg} / \mathrm{mL}$ in phosphate buffered saline) was added to each well, and incubated at $37^{\circ} \mathrm{C}$ for $2 \mathrm{~h}$. The formed formazan crystals were solubilized in $100 \mu \mathrm{L}$ of DMSO, and then measured the absorbance at $570 \mathrm{~nm}$. The percentage cell viability was calculated with respect to solvent control as follows [22]:

$\%$ Cell viability $=$ Abs Compounds $/$ Abs Solvent Control $\mathrm{x} 100$.

Lactate dehydrogenase ( $\mathrm{LDH})$ is a stable cytoplasmic enzyme present in all cells. It is rapidly released into the cell culture supernatant upon damage of the plasma membrane. LDH activity was evaluated using a Roche Cytotoxicity Detection Kit (Roche diagnostics GMBH, Mannheim, Germany) according to the manufacturer instructions. In brief, the mediums of the exposed cells were mixed with the assay reagent prepared by mixing two separate solutions (diaphorase/NAD ${ }^{+}$ mixture and iodotetrazolium chloride/sodium lactate mixture). After incubation for $30 \mathrm{~min}$ at room the temperature and away from the light, the reaction was stopped, and the absorbance was read at $490 \mathrm{~nm}$.
The cell viability was calculated according to the following equation:

$\%$ Cell viability $=100-\left(\mathrm{Abs}_{\text {Compounds }} / \mathrm{Abs}_{\text {Positive Control }} \mathrm{X} 100\right)$.

\section{Results and Discussion}

As a continuation of our previous studies on the antimicrobial effects, of different extracts from 5 Verbascum species and on the chemical content from the most active extract regarding its antimicrobial activity. We aimed to develop the studies and to determine the activity potentials of different extracts from these species. The number of studies on these 3 species, common in the Marmara Region, is quite small, especially on $V$. gnaphalodes and there are no studies, comprising a comparison between their activities and those of the medicinal species. Differently to the previously performed study, the antimicrobial activities of toluene extracts were determined. Furthermore, the antioxidant and cytotoxic activities of various extracts from the aerial parts of 5 Verbascum species and also the antibiofilm activities of the extracts, which showed antimicrobial activity, were investigated. Antioxidant activity: The antioxidant activities were investigated by DPPH and ABTS methods and the contents of the total phenolic compounds were determined (Table I). It was designated that the ethylacetate extracts of VL, VD, VX, VG and VP showed stronger DPPH and $\mathrm{ABTS}^{\cdot+}$ radical scavenging activity than the other extracts. In addition, the ethylacetate extract of VL and all ethylacetate extracts from plants exhibited stronger DPPH radical scavenging and $\mathrm{ABTS}^{\cdot+}$ radical scavenging activity than BHA, respectively. The antioxidant activities of toluene extracts, shown in our study, are remarkable. Additionally, the PE extracts exhibited less antioxidant activity than the other ones. The EtOAc extracts exhibited the highest total phenolic contents (TPC) among other extracts. The EtOAc extracts of VD, VL, VX are remarkable with their TPC $(0.201 \pm 0.009 \mathrm{mg} \mathrm{GAE} / \mathrm{mg}$ extract, $0.194 \pm 0.016 \mathrm{mg}$ GAE $/ \mathrm{mg}$ extract, $0.170 \pm 0.005 \mathrm{mg}$ $\mathrm{GAE} / \mathrm{mg}$ extract; respectively). Also, the $\mathrm{MeOH}$ extracts had higher TPC, especially the VD-MeOH $(0.140 \pm 0.009 \mathrm{mg} \mathrm{GAE} / \mathrm{mg}$ extract$)$. According to these results, there is a linearity between the antioxidant activities and the total phenolic contents.

Table I

DPPH radical scavenging, ABTS radical cation scavenging activities and the amount of total phenolic compounds (TPC) (as gallic acid equivalents) of the different extracts

(These values were the mean values of three replicates \pm standard deviation.)

\begin{tabular}{lccc}
\hline Extracts/Standards & DPPH $\left(\mathbf{I C}_{\mathbf{5 0}} \mathbf{:} \boldsymbol{\mu g} / \mathbf{m L}\right)$ & ABTS $(\mathbf{m M}$ trolox/mg extract) & TPC $(\mathbf{m g}$ GAE/mg extract) \\
\hline $\mathrm{VL}-\mathrm{MeOH}$ & $25 \pm 0.001$ & $83.810 \pm 1.826$ & $0.096 \pm 0.007$ \\
\hline $\mathrm{VL}-\mathrm{PE}$ & $1036 \pm 0.216$ & $7.555 \pm 0.112$ & $0.016 \pm 0.002$ \\
\hline $\mathrm{VL}-\mathrm{Tol}$ & $79 \pm 0.039$ & $54.302 \pm 1.379$ & $0.044 \pm 0.003$ \\
\hline $\mathrm{VL}-\mathrm{CHCl}$ & & $79.843 \pm 0.114$ & $0.057 \pm 0.004$ \\
\hline VL-EtOAc & $84.8 \pm 0.0027$ & $\mathbf{1 3 1 . 2 9 1} \pm \mathbf{0 . 1 0}$ & $\mathbf{0 . 1 9 4} \pm \mathbf{0 . 0 1 6}$ \\
\hline VL-AQ & $\mathbf{5} \pm \mathbf{0 . 0 0 2}$ & $48.334 \pm 0.094$ & $0.042 \pm 0.002$ \\
\hline
\end{tabular}


FARMACIA, 2018, Vol. 66, 6

\begin{tabular}{|c|c|c|c|}
\hline Extracts/Standards & "DPPH $\left(\mathrm{IC}_{50}: \mu \mathrm{g} / \mathrm{mL}\right)$ & "ABTS (mM trolox/mg extract) & 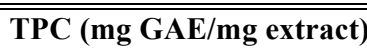 \\
\hline VG-MeOH & $38 \pm 0.002$ & $62.529 \pm 0.1$ & $0.069 \pm 0.003$ \\
\hline VG-PE & $378 \pm 0.051$ & $12.623 \pm 0.284$ & $0.018 \pm 0.001$ \\
\hline VG-Tol & $33 \pm 0.001$ & $52.555 \pm 2.439$ & $0.045 \pm 0.003$ \\
\hline VG-CHCl 3 & $53 \pm 0.001$ & $83.257 \pm 0.591$ & $0.057 \pm 0.004$ \\
\hline VG-EtOAc & $17 \pm 0.001$ & $100.852 \pm 0.19$ & $0.101 \pm 0.006$ \\
\hline VG-AQ & $77 \pm 0.002$ & $41.486 \pm 0.496$ & $0.014 \pm 0.017$ \\
\hline $\mathrm{VX}-\mathrm{MeOH}$ & $13 \pm 0.003$ & $109.514 \pm 0.12$ & $0.124 \pm 0.003$ \\
\hline VX-PE & $326 \pm 0.023$ & $18.772 \pm 0.825$ & $0.019 \pm 0.001$ \\
\hline VX-Tol & $70 \pm 0.001$ & $59.247 \pm 1.08$ & $0.043 \pm 0.001$ \\
\hline $\mathrm{VX}-\mathrm{CHCl}_{3}$ & $92 \pm 0.002$ & $60.014 \pm 0.59$ & $0.042 \pm 0.001$ \\
\hline VX-EtOAc & $9 \pm 0.002$ & $131.102 \pm 0.29$ & $0.170 \pm 0.005$ \\
\hline VX-AQ & $30 \pm 0.003$ & $86.139 \pm 0.188$ & $0.069 \pm 0.002$ \\
\hline VP-MeOH & $28 \pm 0.001$ & $77.824 \pm 0.101$ & $0.081 \pm 0.004$ \\
\hline VP-PE & $623 \pm 0.060$ & $10.636 \pm 0.001$ & $0.017 \pm 0.003$ \\
\hline VP-Tol & $40 \pm 0.001$ & $72.912 \pm 0.47$ & $0.065 \pm 0.003$ \\
\hline VP-CHCl 3 & $70 \pm 0.001$ & $58.865 \pm 1.44$ & $0.039 \pm 0.002$ \\
\hline VP-EtOAc & $26 \pm 0.001$ & $93.321 \pm 0.001$ & $0.091 \pm 0.005$ \\
\hline VP-AQ & $49 \pm 0.001$ & $56.214 \pm 0.66$ & $0.047 \pm 0.001$ \\
\hline VD-MeOH & $7.2 \pm 0.0003$ & $122.167 \pm 1.90$ & $0.140 \pm 0.009$ \\
\hline VD-PE & $523 \pm 0.008$ & $10.022 \pm 0.285$ & $0.015 \pm 0.002$ \\
\hline VD-Tol & $49 \pm 0.001$ & $72.818 \pm 2.2516$ & $0.063 \pm 0.001$ \\
\hline VD-CHCl ${ }_{3}$ & $85.3 \pm 0.001$ & $77.840 \pm 1.477$ & $0.005 \pm 0.001$ \\
\hline VD-EtOAc & $7.4 \pm 0.001$ & $131.479 \pm 0.10$ & $0.201 \pm 0.009$ \\
\hline VD-AQ & $33 \pm 0.001$ & $74.225 \pm 0.281$ & $0.051 \pm 0.041$ \\
\hline BHA & $6 \pm 0.60$ & $52.63 \pm 0.01$ & - \\
\hline Ascorbic acid & $4 \pm 0.90$ & - & - \\
\hline
\end{tabular}

Antimicrobial activity: All extracts were tested for their antimicrobial activity against Gram positive/Gram negative bacteria and yeast. While no antibacterial activity was registered by VX-PE against all bacteria, the other extracts of VL, VX and VG, except VL-AQ, exhibited good antibacterial activity against $S$. aureus, $S$. epidermidis and $E$. faecalis with MIC values between 156 and $1250 \mu \mathrm{g} / \mathrm{mL}$. VL-AQ showed an activity only against $S$. aureus and E. faecalis. The extracts of VP and VD were active against all Gram positive bacteria (S. aureus, S. epidermidis, E. faecalis), generally. VP$\mathrm{MeOH}$ and VD-MeOH were found active against $S$. aureus and $S$. epidermidis as well as VD-PE against
$S$. epidermidis and E. faecalis. The extracts of VP were more active against Gram positive bacteria than the VD-extracts.

The VL-EtOAc was found the most active against Gram positive bacteria with the concentrations of 156 and $625 \mu \mathrm{g} / \mathrm{mL}$. Also, VL-EtOAc was the only active extract against $K$. pneumoniae. Against $P$. aeruginosa, only 3 VL-extracts (VL-MeOH, VL-EtOAc and VLPE) possessed important activity. The most active antifungal extract was VL-EtOAc $(156 \mu \mathrm{g} / \mathrm{mL})$. Overall, the best results were given by the VL-extracts, especially VL-EtOAc, against all bacteria and yeast, even better than the extracts of medicinal species (Table II).

Table II

In vitro antimicrobial activities of the different extracts

\begin{tabular}{|c|c|c|c|c|c|c|c|c|}
\hline \multicolumn{9}{|c|}{ MIC values $(\mu \mathrm{g} / \mathrm{mL})$} \\
\hline Extracts & $\mathbf{S a}$ & Se & Ef & Ec & $\mathbf{K p}$ & Pm & $\mathbf{P a}$ & $\mathbf{C a}$ \\
\hline VL- MeOH & ++ & + & + & - & - & - & ++ & ++ \\
\hline VL-PE & + & +++ & + & - & - & - & ++ & ++ \\
\hline VL-Tol & + & ++ & + & - & - & - & - & ++ \\
\hline $\mathrm{VL}-\mathrm{CHCl}_{3}$ & ++ & + & + & - & - & - & - & ++ \\
\hline VL-EtOAc & ++++ & ++ & ++ & - & +++ & - & +++ & ++++ \\
\hline VL-AQ & +++ & - & ++ & - & - & - & - & +++ \\
\hline VG- $\mathrm{MeOH}$ & + & + & + & - & - & - & - & ++ \\
\hline VG-PE & + & + & + & - & - & - & - & ++ \\
\hline VG-Tol & + & ++ & + & - & - & - & - & ++ \\
\hline $\mathrm{VG}-\mathrm{CHCl}_{3}$ & + & + & + & - & - & - & - & ++ \\
\hline VG- EtOAc & + & + & + & - & - & - & - & ++ \\
\hline VG-AQ & + & + & + & - & - & - & - & - \\
\hline $\mathrm{VX}-\mathrm{MeOH}$ & + & + & + & - & - & - & - & ++ \\
\hline
\end{tabular}


FARMACIA, 2018, Vol. 66, 6

\begin{tabular}{|c|c|c|c|c|c|c|c|c|}
\hline \multicolumn{9}{|c|}{ MIC values $(\mu \mathrm{g} / \mathrm{mL})$} \\
\hline Extracts & $\mathbf{S a}$ & Se & Ef & Ec & Kp & Pm & $\mathbf{P a}$ & $\mathbf{C a}$ \\
\hline VX-PE & - & - & - & - & - & - & - & ++ \\
\hline VX-Tol & + & ++ & + & - & - & - & - & ++ \\
\hline $\mathrm{VX}-\mathrm{CHCl}_{3}$ & + & + & + & - & - & - & - & - \\
\hline VX- EtOAc & + & + & + & - & - & - & - & ++ \\
\hline VX-AQ & + & + & + & - & - & ++ & - & - \\
\hline VP- $\mathrm{MeOH}$ & + & + & - & - & - & ++ & - & ++ \\
\hline VP-PE & + & ++ & + & - & - & ++ & - & ++ \\
\hline VP-Tol & + & ++ & ++ & - & - & - & - & ++ \\
\hline VP- $\mathrm{CHCl}_{3}$ & + & ++ & + & - & - & - & - & ++ \\
\hline VP- EtOAc & + & + & + & - & - & - & - & ++ \\
\hline VP-AQ & + & + & + & - & - & ++ & - & ++ \\
\hline VD- $\mathrm{MeOH}$ & + & + & - & - & - & ++ & - & - \\
\hline VD-PE & - & + & + & - & - & - & - & ++ \\
\hline VD-Tol & + & ++ & + & - & - & - & - & ++ \\
\hline VD- $\mathrm{CHCl}_{3}$ & + & + & + & - & - & - & - & ++ \\
\hline VD- EtOAc & + & + & + & - & - & - & - & ++ \\
\hline VD- AQ & + & ++ & + & - & - & - & - & - \\
\hline
\end{tabular}

Sa: S. aureus ATCC 6538; Se: S. epidermidis ATCC 12228; Ef: E. faecalis ATCC; Ec: E. coli ATCC 25922; Kp: K. pneumoniae ATCC 4352; Pm: P. mirabilis ATCC 14153; Pa: P. aeruginosa ATCC 27853; Ca: C. albicans ATCC 10231; $1250 \mu \mathrm{g} / \mathrm{mL}=+$; $625 \mu \mathrm{g} / \mathrm{mL}=++; 312.5 \mu \mathrm{g} / \mathrm{mL}=+++; 156 \mu \mathrm{g} / \mathrm{mL}=++++;-$ : no inhibition

Antibiofilm activity: All extracts, which were found to have antimicrobial activity, were tested for their antibiofilm effect. It was determined that none of the extracts were active against the biofilm even at the concentration of $10.000 \mu \mathrm{g} / \mathrm{mL}$.

Cytotoxicity potentials: The cytotoxic potentials of the extracts were investigated on the normal NRK52E rat kidney cell line at the effective concentrations in the antioxidant and antimicrobial tests. The VDextracts (except VD-CHCl 3 and VD-TOL), VG-AQ, VL-EtOAc, VL-MeOH and VX-AQ were non-toxic at the tested concentrations by MTT and LDH methods. The nonpolar extracts exhibited higher cytotoxicity than the polar extracts. The extracts of the medicinal species, VP and VG, showed toxicity at higher concentrations in contrast to the other extracts. However, it is designated that, the samples were much more active in LDH test than in MTT test (Table III).

Table III

The $\mathrm{IC}_{50}$ values $(\mu \mathrm{g} / \mathrm{mL})$ of the extracts in MTT

\begin{tabular}{|l|c|c|}
\hline \multicolumn{1}{|c|}{ Extracts } & $\begin{array}{c}\text { MTT } \\
\text { IC }_{\mathbf{5 0}}(\boldsymbol{\mu g} / \mathbf{m L})\end{array}$ & $\begin{array}{c}\text { LDH } \\
\text { IC }_{\mathbf{5 0}}(\boldsymbol{\mu g} / \mathbf{m L})\end{array}$ \\
\hline VL- MeOH & - & - \\
\hline VL-PE & 0.224 & - \\
\hline VL-TOL & 0.006 & 0.048 \\
\hline VL-CHCl ${ }_{3}$ & 0.108 & - \\
\hline VL-EtOAc & - & - \\
\hline VL-AQ & 0.138 & - \\
\hline VG- MeOH & 0.092 & - \\
\hline VG-PE & 0.041 & 0.198 \\
\hline VG-TOL & 0.064 & 0.065 \\
\hline VG- CHCl & \\
\hline VG- EtOAc & 0.197 & - \\
\hline VG- AQ & 0.099 & - \\
\hline VX- MeOH & - & - \\
\hline VX-PE & 0.019 & - \\
\hline
\end{tabular}

\begin{tabular}{|l|c|c|}
\hline \multicolumn{1}{|c|}{ Extracts } & $\begin{array}{c}\text { MTT } \\
\mathbf{I C}_{\mathbf{5 0}}(\boldsymbol{\mu} \mathbf{g} / \mathbf{m L})\end{array}$ & $\begin{array}{c}\text { LDH } \\
\mathbf{I C}_{\mathbf{5 0}}(\boldsymbol{\mu} \mathbf{g} / \mathbf{m L} \mathbf{L})\end{array}$ \\
\hline VX-TOL & 0.024 & 0.042 \\
\hline VX- CHCl ${ }_{3}$ & 0.023 & 0.198 \\
\hline VX- EtOAc & 0.006 & - \\
\hline VX- AQ & - & - \\
\hline VP- MeOH & 0.113 & 0.230 \\
\hline VP-PE & 0.017 & - \\
\hline VP-TOL & 0.089 & 0.095 \\
\hline VP- CHCl & 0.037 & - \\
\hline VP- EtOAc & 0.035 & - \\
\hline VP- AQ & - & 0.141 \\
\hline VD- MeOH & - & - \\
\hline VD-PE & - & - \\
\hline VD-TOL & 0.038 & 0.078 \\
\hline VD- CHCl & 0.057 & 0.219 \\
\hline VD- EtOAc & - & - \\
\hline VD- AQ & - & - \\
\hline
\end{tabular}

Nowadays, the antioxidant and antimicrobial agents have an important place in everyday life. Also, the food preservation is very important for a healthy life. The organic biomolecules are one of the methods for food preservation. The consumers concern about foods without/with lower levels of chemical preservatives because of their possible toxic effects and demand for the long shelf-life of food and absence of risk of causing foodborne diseases. Therefore, the food industry tries to find alternative natural sources instead of the chemical preservatives. The usage of chemical preservatives can result in obtaining resistant microbial strains to classic antimicrobial agents. At this point, the natural alternatives take important place in food conservation, especially the plants. There are many studies on plants, which present excellent antimicrobial properties, but the usage to enhance the shelf stability of foods were restricted. 
The plants have excellent antimicrobial activity and contain many compounds, which have a role in their antimicrobial activity and are collectively called green chemicals. Wilkins and Board reported over 1389 plants as potential green chemical sources, and more specifically by the identification of over 250 new antifungal metabolites in plants between 1982 and 1993. It has been recognized that, investigations are now focused on the potential use of phytoalexins, organic acids, and phenols [4, 10, 11, 17, 19, 35, 40]. In literature, some articles investigated the antioxidant activities of $V$. wiedemannianum Fisch. et Mey. (the inhibition rate of $52.5 \% \pm 3.11$ ) and $V$. cheiranthifolium Boiss. $[3,7]$. Dalar et al. investigated the lyophilized hydrophilic extract of $V$. cheiranthifolium Boiss. var. cheiranthifolium Boiss. at non-toxic concentrations and it exhibited the suppression of the accumulation of nitric oxide (NO) in lipopolysaccharide (LPS)activated murine macrophages (RAW 264.7) and hepatocellular carcinoma (HepG2) cells [8]. In another study, in which 2,2-diphenyl-1-picrylhydrazyl (DPPH), oxygen radical absorbance capacity (ORAC) and total phenolic content (TPC) assays together with MTT cell viability assay (performed on Hep-G2 and MRC-5) were used, 18 Ethiopian medicinal plants were investigated for their antioxidant and antiproliferative activity. The extract of $V$. sinaiticum Benth. showed one of the most potent cytotoxic results [37]. The methanolic and hydrophilic extracts of Verbascum species showed antioxidant activity. Thusly, Verbascum species in this study indicate an important antioxidant activity.

Quave et al. tested V. sinuatum L. and V. thapsus, for their inhibition of growth and biofilms in methicillinresistant $S$. aureus (MRSA) and found the extracts of these two species inactive [28]. In addition, a study on the antibacterial activity of the methanolic extract from $V$. sinuatum inflorescences and its chemical constituents were reported in the literature [32]. In spite of the antimicrobial results of studied Verbascum species, they did not exhibit an antibiofilm activity. According to all previously mentioned information and results, the importance of antimicrobial and antioxidant activities in food preservation come in view. From the standpoint of the role of phenolic compounds in food preservation and the results regarding the phenolic content and the activities of Verbascum species, these species can have a food preservative potential. Likewise, studied Verbascum species shown good antioxidant and antimicrobial activities. Considering all reviewed aspects, the Verbascum species can be used as food preservative agents; the VL-EtOAc as an antioxidant agent as well as antimicrobial agent and as food preservative; the extract VD-EtOAc as an agent with good antioxidant activity.

\section{Conclusions}

This study represents a comparison of the activity profiles of 5 Verbascum species. It is remarkable that, the VL-EtOAc was found nontoxic at the effective concentrations in the antioxidant and antimicrobial tests. This extract can be assigned as an antioxidant agent as well as antimicrobial agent. This extract can also be used for food preservation. Beside of this, the extract VD-EtOAc can be designated as a good antioxidant agent.

\section{Acknowledgement}

The authors would like to thank Ass. Prof. Dr. Leyla Bitis for making possible the study at the Marmara University, Faculty of Pharmacy, Department of Pharmacognosy and to thank Ms. Meltem Kurtsan from Kurtsan Holding, Istanbul for supplying the aerial parts of $V$. phlomoides.

\section{References}

1. Abu AB, Zuraini Z, Lacimanan YL, Sreenivasan S, Antioxidant activity and phytochemical screening of the methanol extracts of Euphorbia hirta L. Asian Pac J Trop Dis., 2011; 4: 386-390.

2. Baytop T, Türkiye'de Bitkilerle Tedavi (Geçmişte ve Bugün). Nobel Tip Kitabevleri Ltd., Istanbul, 1999: 334-335.

3. Bektas T, Sokmen M, Akpulat HA, Yumrutas O, Sokmen A, Screening of antioxidant properties of the methanolic extracts of Pelargonium endlicherianum Fenzl., Verbascum wiedemannianum Fisch \& Mey., Sideritis libanotica Labill. subsp. linearis (Bentham) Borm., Centaurea mucronifera DC. and Hieracium cappadocicum Freyn from Turkish flora. Food Chem., 2006; 98: 9-13.

4. Brull S, Coote P, Preservative agents in foods: mode of action and microbial resistance mechanisms. Int J Food Microbiol., 1999; 50: 1-17.

5. Clinical and Laboratory Standards Institute (CLSI), Reference Method for Broth Dilution Antifungal Susceptibility Testing of Yeasts; Approved Standard M27-A NCCLS, Wayne, Pennsylvania, 2000.

6. Clinical and Laboratory Standards Institute (CLSI), Methods for dilution antimicrobial susceptibility tests for bacteria that grow aerobically: Approved Standard M7-A5. Wayne, Pennsylvania, 2006.

7. Dalar A, Konczak I, Botanicals from Eastern Anatolia Region of Turkey: Antioxidant capacity and phenolic constituents of endemic herbal medicines. J Herb Med., 2012; 2: 126-135.

8. Dalar A, Guo Y, Konczak I, Phenolic composition and potential anti-inflammatory properties of Verbascum cheiranthifolium var. cheiranthifolium leaf. J Herb Med., 2014; 4: 195-200.

9. Davis PH, (Ed.), Flora of Turkey and the East Aegean Islands. Vol VI. Edinburgh University Press, Edinburgh, 1988: 478-603.

10. Delaquis PS, Mazza G, Antimicrobial Properties of Isothiocyanates in Food Preservation. Food Technol., 1995; 49: 73-84. 
FARMACIA, 2018, Vol. 66, 6

11. De Souza EL, Stamford TLM, de Oliveira Lima E, Trajano VN, Filho JMB, Antimicrobial Effectiveness of Spices: An Approach for Use in Food Conservation Systems. Braz Arch Biol Technol., 2005; 48: 549-558.

12. Dosler S, Mataraci E, Baspinar-Kucuk H, Yusufoglu A, Antibacterial and antibiofilm activities of new chiral and racemic 1,3-Dioxolanes. J Fac Pharm Istanbul, 2015; 45: 19-28.

13. Ekim T, Verbascum L, In Guner A, Ozhatay N, Ekim T, Baser KHC, (Eds.), Flora of Turkey and the East Aegean Islands (Supplement 2), Edinburgh University Press, Edinburgh, 2000: 193.

14. Georgiev MI, Metabolic differentiations and classification of Verbascum species by NMR-based metabolomics. Phytochemistry, 2011; 72: 2045-2051.

15. Georgiev M, Alipieva K, Orhan I, Abrashev R, Denev $\mathrm{P}$, Angelova M, Antioxidant and cholinesterases inhibitory activities of Verbascum xanthophoeniceum Griseb. and its phenylethanoid glycosides. Food Chem., 2011; 128: 100-105.

16. Georgiev M, Pastore S, Lulli D, Alipieva K, Kostyuk V, Potapovich A, Panetta M, Korkina L, Verbascum xanthophoeniceum - derived phenylethanoid glycosides are potent inhibitors of inflammatory chemokines in dormant and interferon-gamma-stimulated human keratinocytes. J Ethnopharmacol., 2012; 144: 754-760.

17. Grayer RJ, Harborne JB, A survey of antifungal compounds from higher plant, 1982-1993. Phytochemistry, 1994; 37: 19

18. Huber-Morath A, Verbascum L. in Davis PH, (Ed.), Flora of Turkey and the Central Aegean Islands, Vol. 6, Edinburgh University Press, Edinburgh, 1978: 461-603.

19. Jenner PM, Hagan EC, Taylor JM, Cook EL, Fitzhugh OG, Food flavourings and compounds of related structure. I. Acute oral toxicity. Food Cosmet Toxicol., 1964; 2: 327-343.

20. Marcoccia D, Georgiev MI, Alipieva KI, Lorenzetti $\mathrm{S}$, Inhibition of the DHT-induced PSA secretion by Verbascum xanthophoeniceum and Serenoa repens extracts in human LNCaP prostate epithelial cells. $J$ Ethnopharmacol., 2014; 155: 616-625.

21. Mataraci E, Dosler S, In vitro activities of antibiotics and antimicrobial cationic peptides alone and in combination against methicillin resistant Staphylococcus aureus biofilms. Antimicrob Agents Chemother., 2012; 56: 6366-6371.

22. Mosmann T, Rapid colorimetric assay for cellular growth and survival: application to proliferation and cytotoxicity assays. J Immunol Methods, 1983; 65: 55-63.

23. Ozhatay N, Kultur S, Check-List of Additional Taxa to the Supplement Flora of Turkey III. Turk J Bot., 2006; 30: 281-316.

24. Ozhatay N, Kultur S, Aslan S, Check-list of Additional Taxa to the Supplement Flora of Turkey IV. Turk $J$ Bot., 2009; 33: 191-226.

25. Ozhatay N, Kultur S, Gurdal B, Check-list of Additional Taxa to the Supplement Flora of Turkey V. Turk $J$ Bot., 2011; 35: 589-624.
26. Ozhatay N, Kultur S, Gurdal B, Check-list of Additional Taxa to the Supplement Flora of Turkey VI. J Fac Pharm Istanbul, 2013; 43: 33-82.

27. Ozhatay N, Kultur S, Gurdal B, Check-list of Additional Taxa to the Supplement Flora of Turkey VII. J Fac Pharm Istanbul, 2015; 45: 61-86.

28. Quave CL, Plano LRW, Pantuso T, Bennett BC, Effects of extracts from Italian medicinal plants on planktonic growth, biofilm formation and adherence of methicillin-resistant Staphylococcus aureus. J Ethnopharmacol., 2008; 118: 418-428.

29. Re R, Pellegrini N, Proteggente A, Pannala A, Yang M, Rice-Evans C, Antioxidant activity applying an improved ABTS radical cation decolorization assay. Free Radic Biol Med., 1999; 26: 1231-1237.

30. Sen B, Dosler S, Mericli AH, Chemical Constituents and Antimicrobial Activity of Verbascum lagurus. Chem Nat Compd., 2015; 51: 139-140.

31. Sen B, Dosler S, Mericli AH, The Antimicrobial Activity Screening of Three Verbascum Species In Marmara Region (Turkey). Planta Med., 2012; 78: PI310. $\left(60^{\text {th }}\right.$ International Congress (Joint Meeting with ASP, AFERP, PSE and SIF) and Annual Meeting of GA, New York, ABD, 28 Temmuz - 1 Ağustos 2012; 78: PI310-PI310).

32. Senatore F, Rigano D, Formisano C, Grassia A, Basile A, Sorbo S, Phytogrowth-inhibitory and antibacterial activity of Verbascum sinuatum. Fitoterapia, 2007; 78: 244-247

33. Sezik E, Yesilada E, Honda G, Takaishi Y, Takeda Y, Tanaka T, Traditional medicine in Turkey X. Folk medicine in Central Anatolia. J Ethnopharmacol., 2001; 75: 95-115.

34. Slinkard K, Singleton VL, Total phenol analyses: automation and comparison with manual methods. Am J Enology Viticulture, 1977; 28: 49-55.

35. Smid EJ, Gorris LGM, Natural Antimicrobials for Food Preservation. In: Rahman MS, (Ed.), Handbook of Food Preservation. ( $2^{\text {nd }}$ Ed.). CRC Press, New York, 2007: 285

36. Tan N, Sen B, Bilgin M, Tan E, Antimicrobial activity of extracts from an endemic Salvia cilicica Boiss. and Kotschy. Afr J Microbiol Res., 2015; 9: 130-134.

37. Tauchen J, Doskocil I, Caffi C, Lulekal E, Marsik P, Havlik J, Van Damme P, Kokska L, In vitro antioxidant and anti-proliferative activity of Ethiopian Medicinal Plant Extracts. Ind Crops Prod., 2015; 74: 671-679.

38. Tuzlacı E, Erol MK, Turkish folk medicine plants. Part II: Eğirdir (Isparta). Fitoterapia, 1999; 70: 593-610.

39. Wei F, Chen J, Cai Y, Lei Y, Chen L, Pei L, Zhou D, Liang X, Ruan J, Antioxidant, free radical scavenging, anti-inflammatory and hepatoprotective potential of the extract from Parathelypteris nipponica (Franch.et Sav.) Ching. J Ethnopharmacol., 2010; 130: 521-528.

40. Wilkins KM, Board RG, Natural antimicrobial systems. In: Gould GW, (Ed.). Mechanisms of Action of Food Preservation Procedures. Elsevier Applied Science, London, 1989: 305. 